DOI: https://doi.org/10.46811/apjnh/3.2.1

Original Research Article

\title{
Identification of the relationship between nursing students' kolb learning styles and problem-solving skills
}

\author{
Seda ŞAHAN, Ayşegül YILDIZ, Sevil ŞAHIN \\ ${ }^{I}$ Seda Sahan, Research Assistant, Nursing Fundamentals Departmant, İzmir Bakırçay Untversity, Turkey \\ ${ }^{2}$ Ayşegul Yildiz, Teaching assistant, Dialysis Department, Cappadocia Vocational School, Cappadocia \\ University, Turkey \\ ${ }^{3}$ Sevil sahin, Asst. Prof., Nursing Fundamentals Departmant, Erciyes University, Turkey
}

*Correspondence

Seda ŞAHAN, Research Assıstant, Nursing Fundamentals Departmant, İzmir Bakırçay Unıversıty, Turkey.

E-mail:seda.sahan@ bakircay.edu.tr

Orcid Id: 0000-0003-4071-2742

Received: 20-05-2020 / Revised: 29-06-2020 / Accepted: 30-07-2020

\begin{abstract}
Introduction: In order to maintain nursing care in the most effective and quality way in There lationship between patient and nurse and nurses to manage this dynamic process, problem solving skills must be developed. Individuals in the learning environment are people who are independent from each other and have different characteristics and share the same environment. Objectives: To determine the learning styles of individuals and to manage the education process. Method: This study was planned to determine There lationship between the learning styles and problem solving skills of the students who received nursing education. The universe of There search consisted of 130 students in İzmir Bakırçay University Faculty of Health Sciences Nursing Department. In the study, the data were collected between 1-29 February 2020. Results: It was determined that $26.9 \%$ of the students participating in the study were male and $73.1 \%$ were female. It was observed that $33.8 \%$ of the students had learning style that parses, $22.3 \%$ changes, $28.5 \%$ assimilates and $15.4 \%$ places. It was determined that the problem solving skills of the students were moderate according to the score they received from the problem solving inventory $(X=82,09)$. There was a significant relationship between participants' general problem solving approach levels and Kolb learning style groups $(\mathrm{p}=0.04)$. Conclusion: It is thought that the education given to students' learning styles will support their problem solving skills and the success rate will increase.
\end{abstract}

Keywords: Nursing, Learning Styles, Problem solving skill.

This is an Open Access article that uses a fund-ing model which does not charge readers or their institutions for access and distributed under the terms of the Creative Commons Attribution License (http://creativecommons.org/licenses/by/4.0) and the Budapest Open Access Initiative (http://www.budapestopenaccessinitiative.org/read), which permit unrestricted use, distribution, and reproduction in any medium, provided the original work is properly credited.

\section{Introduction}

So that effective learning will be achieved in the process of education and instruction, it is necessary to identify student characteristics. In the instruction process, students with different skill levels partake in the learning setting. Students' learning methods and their perception and memorization skills can differ from each other $[1,2]$. That is why, the learning and instruction process should be planned and implemented by taking into consideration the personal differences of students who are recipients of education [3].In the instruction format which pays attention to personal differences, identifying individuals' learning styles is the most decisive factor. Students' learning styles determine the format of education to be given to them. How the student will be included in the learning process, how he/she will develop critical-thinking, decision-making and problem-solving skills and how he/she will get competency in these domains will be shaped by virtue of the identification of learning styles [4]. 
The achievement level of each student differs from each other even if the learning setting presents equal opportunities to all students.This situation actually arises from the fact that learning styles vary across students.In recent studies, it was asserted that the instruction setting organized around learning styles owned by students acted as a crucial factor $[5,6]$.

Studies on learning styles were for the first time launched by Rita Dunn in 1960 and different learning styles were defined.One of these learning styles addressed by researchers is Kolb Learning Styles.Kolb learning styles referred to the learning which was based on ways preferred by the individual for processing and collecting data and which was derived from experience.The learning based on experience arises from individual's use of perception, talent and execution capacity as a whole.Kolb's four learning stages are Concrete Experience, Reflective Observation, Abstract Conceptualization and Active Experimentation.In Concrete Experience stage, students actively take part in a new experiment/case and explore the experience in this case.In Reflective Observation stage, students analyze data by means of watching and observing.Students who explain their observations and create theories in Abstract Conceptualization stage use theories for problemsolving and put these theories into practice in Active Experimentation stage.Even if four learning stages are defined with regard toindividuals' talents, learning styles are determined by constituentparts of these four stages.Kolb learning styles have four dimensions, that is, accommodating, assimilating, diverging and converging [7].

In Turkey, several studies were performed on nursing students by utilizing 'Kolb Learning Style Inventory'.Results of these studies demonstrate that the dominant learning styles for the majority of students were 'converging' and 'assimilating' whereas a smaller number of students had 'accommodating' and 'diverging' learning styles[8-10]. Zamanzadeh[2008] indicated that $54.2 \%$ of nursing and midwifery students had 'converging' learning style whilst $32.1 \%$ of them had assimilating learning style[11]. Moreover, in a study conducted on Iranian nursing students [2007], it was ascertained that, of all student participants, $23.2 \%$ had 'converging' learning style, $25.8 \%$ had 'assimilating' learning style, $29.4 \%$ had 'diverging' learning style and $21.5 \%$ had 'accommodating' learning style [12].

Nurses are health professionals who identify individuals' different healthcare needs, place these needs in order of priorities, offer nursing care specific to each need and are obliged to evaluate the results of healthcare to be offered.One of the most important determinants which indicate whether nurses can provide safe and good quality healthcare pertains to their problem-solving skills [11]. Nurses endowed with problem-solving skills have advanced coping skills, skills in understanding and evaluating sophisticated circumstances and skills in developing solutions, and hence it becomes possible to enhance the quality of nursing service.Having information on students' learning styles and problem-solving skills during nursing education will directly affect their academic and clinical achievement levels. Therefore, it is essential to identify students' learning styles [13].

Students can productively complete the learning process if education programs are prepared in light of individuals' learning styles and if individuals' problem-solving skills are developed. In the literature, there was no study analyzing the relationship between Kolb learning styles and the problem-solving skill. Thus, this study was performed for identifying students' learning styles and analyzing the relationship between their learning styles and problem-solving skills.

\section{Material \& Methodology}

This study was performed for identifying the relationship between nursing students' Kolb learning styles and their problem-solving skills. This research was conducted at the Department of Nursing of Health Sciences Faculty of İzmir Bakırçay University. In the nursing department, there are only two classes. 80 firstyear students and 60 second-year students are enrolled at the nursing department.

\section{Population and Sample}

Research population was comprised of 130 students who were enrolled at the Department of Nursing of Health Sciences Faculty of İzmir Bakırçay University. In the research, no sample was selected from the population, rather, the entire population was designated as the research sample. 10 students were excluded from the sample as they either dropped out of the university or rejected to take part in the research.In the research, data were collected from February1 to February 29, 2020, through Student Information Form, Kolb Learning Style Inventory and Problem-Solving Inventory.Research data were collected through faceto-face interviews. Each interview took approximately 10-15 minutes. During interviews, researchers stood by students, and students' questions on forms were answered by researchers.

\section{Data Analysis}

Statistics about students' demographic characteristics and the scores obtained by students from each 
inventory and their sub-scales were expressed as means, standard deviations, frequencies and percentages. In the framework of the study, Independent Samples T-Test, Chi-Squared Test, variance analysis and correlation analysis were carried out. In analyses, statistical significance was identified if the $P$ value was lower than $0.05 \quad[\mathrm{p}<0.05]$, and analyses were conducted via SPSS 22.0 software.

\section{Results}

It was ascertained that, of all participant students, $26.9 \%$ were male and $73.1 \%$ were female.

It was discerned that, of all participant students, 33.8\% had converging learning style $[n=44], 22.3 \%$ had diverging learning style $[\mathrm{n}=29], 28.5 \%$ had assimilating learning style $[\mathrm{n}=37]$ and $15.4 \%$ had accommodating learning style $[\mathrm{n}=20]$.

It was found that participants' academic success level had no statistically significant relationship with 'Concrete Experience', 'Reflective Observation', 'Abstract Conceptualization' and 'Active Experimentation' learning levels of participants [p>0.05]

It was discerned that, on the basis of students' genders, there was a statistically significant difference in students' Kolb learning style levels.

As per the table, means of scores obtained by nursing students from the overall Problem-Solving Inventory and its sub-scales demonstrate that nursing students had medium-level problem-solving skills.

It was ascertained that participants' academic success levels had weak statistically significant positive relationship with hasty, thinking, avoidance, evaluating, self-confident, planned approaches and the overall problem-solving approach.

It was found that participants' thinking approach levels [p=0.02], avoidance approach levels $[\mathrm{p}=0.04]$ and evaluating approach levels $[\mathrm{p}=0.03]$ had statistically significant associations with sub-scales of Kolb Learning Style Inventory. However, it was discerned that participants' self-confident approach levels $[\mathrm{p}=0.25]$, hasty approach levels $[\mathrm{p}=0.88]$ and planned approach levels $[\mathrm{p}=0.29]$ had no statistically significant associations with sub-scales of Kolb Learning Style Inventory. On the other hand, it was observed that participants' overall problem-solving approach levels had a statistically significant association with subscales of Kolb Learning Style Inventory [p=0.04].

\section{Discussion}

Learning is a process in which the student plays an active role [14]. Having information on learning styles helps to get acquainted with strengths and weaknesses of individuals. Thus, the learning process is shaped in a manner to be well-suited to each individual [15]. In the process of nursing care, the problem-solving skill is quite essential. Meeting the nursing needs of the patient through the analysis and synthesis of data obtained from the patient requires nurses to employ problemsolving skills. During nursing education, students are anticipated to achieve in obtaining problem-solving skills. In order to attain this achievement, it is necessary to plan the education on the basis of student needs [11].

In the current study, it was found that, of all students involved with the study, $26.9 \%$ were male and $73.1 \%$ were female [Table 1].Besides, it was ascertained that participant students mostly had converging learning style [33.8\%] and assimilating learning style [28.5\%] whereas the accommodating learning style [15.4\%] was the least common among participant students [Table 2].These findings are in parallel to results of studies which were performed with nursing students in Turkey and suggested that students mostly had assimilating and converging learning styles [8, 1618].Also, the study by Shirazi et al. put forward that nursing students mostly had converging learning style[19].Assimilating learning style basically rests on the identification of the problem and the development ofthetheory.Converging learning style, on the other hand, embraces the learning via problem-solving, decision-making, ability to analyze and laboratory practices [20]. In nursing education, converging and assimilating learning styles represent the foundations of nursing and nursing education.Therefore, the education should be planned in a way to equip students with the ability to identify problems and produce solutions and to analyze and synthesize and with a critical perspective. Nevertheless, this situation does not signify that the education of students with diverging and accommodating learning styles is to be neglected. Instructors should organize the education by taking into consideration all learning styles.

Moreover, in the current study, it was found that there was no statistically significant relationship between academic success and learning styles [p>0.05] [Table 3]. In support of this finding, the study by Güven et al. asserted that there was no statistically significant association between students' academic achievements and their learning styles. The study conducted by Phuong et al. on the second year students showed that there was no statistically significant relationship between students' academic achievements and their Kolb learning styles[21]. On the basis of these results, it is thought that learning styles had no association with success and intelligence, and a learning style was not superior to any other learning style. 
Besides, as per results of this current study, means of scores obtained by nursing students from the overall Problem-Solving Inventory and its sub-scales indicated that nursing students had medium-level problemsolving skills [Table 4].In support of this result, there are several studies in which it was found that students' problem-solving skills were at medium level [11, 2228].In another study, the effect of case-based learning on problem-solving skills was analyzed.At the beginning of the research, problem-solving skills of experimental group and the group of students having the course in conventional format were at medium level and analogous to each other.However, at the end of the research, it was argued that problem-solving skills of students who were in the group having casebased instructionwent up[29]. From this result, it is inferred that, if students are provided with instruction well-suited to their needs and learning styles, it is likely to have enhancement in their problem-solving skills.

Additionally, in the current study, it was ascertained that there was a statistically significant relationship between students' academic achievements and problem-solving skills [Table 5]. Results of the study by Özyağcioğlu et al. are analogous to this current study[30]. It is asserted that individuals with high-level problem-solving skills were more successful than other individuals in their academic careers[31]. As per this result, it can be deduced that students endowed with problem-solving skills possesseda stronger ability to analyze and also students' problem-solving skills facilitated the learning process.

Moreover, in the current study, it was discerned that there was a statistically significant relationship between participants' thinking approach levels and sub-scales of Kolb Learning Style Inventory [Table 6].
It was found that participants with 'accommodating' learning style had the highest thinking approach levels than participants with other learning styles did $[p=0.02]$.Individuals with 'accommodating' learning style are inclined to act on intuition and trust the information given by other people.In a rational manner, they evaluate the information which they obtain from other people, and take in the information which is relevant to their needs $[32,33]$.It can be concluded that the identification of problems alongside thinking approach and the selection of the relevant idea upon questioning other ideas without making hasty decisions support the accommodating learning style.It is supposed that individuals will be more successful in selecting the most relevant idea out of other ideas by virtue ofamalgamating thinking approach and accommodating learning style.

Lastly, in the study, it was ascertained that there was a statistically significant relationship between participants' evaluating approach levels and Kolb learning styles [Table 6].It was discerned that evaluating approach levels of participants who had accommodating and converging learning styles were higher than those of participants who had diverging and assimilating learning styles [ $\mathrm{p}=0,03]$. Noteworthy characteristics owned by individuals with converging learning style are problem-solving, analyzing, decisionmaking and situation planning.It is asserted that individuals endowed with this style were successful in problem-solving [34, 35].Along with this result, it is considered that, together with evaluating approach, individuals with converging learning style will have enhanced ability to analyze and synthesize problems, and individuals equipped with evaluating approach will be more successful in evaluating theories and putting forward the areas for practical application.

Table 1: General Features of Students

\begin{tabular}{|l|l|l|}
\hline Gender & $\mathrm{n}$ & $\%$ \\
\hline Male & 35 & 26,9 \\
\hline Female & 95 & 73,1 \\
\hline
\end{tabular}

It was ascertained that, of all participant students, $26.9 \%$ were male and $73.1 \%$ were female [Table 1].

Table 2: Students' Kolb Learning Styles

\begin{tabular}{|l|l|l|}
\hline Kolb Learning Styles & $\mathrm{n}$ & $\%$ \\
\hline Converging & 44 & 33,8 \\
\hline Diverging & 29 & 22,3 \\
\hline Assimilating & 37 & 28,5 \\
\hline Accommodating & 20 & 15,4 \\
\hline
\end{tabular}


It was discerned that, of all participant students, 33.8\% had converging learning style [ $=44], 22.3 \%$ had diverging learning style [ $\mathrm{n}=29], 28.5 \%$ had assimilating learning style [ $\mathrm{n}=37]$ and $15.4 \%$ had accommodating learning style $[\mathrm{n}=20]$ [Table 2].

Table 3: Relationship between students' success levels and Kolb learning stages

\begin{tabular}{|l|l|l|l|l|l|}
\hline \multicolumn{2}{|l|}{ Student characteristics } & $\begin{array}{l}\text { Concrete } \\
\text { Experience }\end{array}$ & $\begin{array}{l}\text { Reflective } \\
\text { Observation }\end{array}$ & $\begin{array}{l}\text { Abstract } \\
\text { Conceptualization }\end{array}$ & $\begin{array}{l}\text { Active } \\
\text { Experimentation }\end{array}$ \\
\hline $\begin{array}{l}\text { Grade } \\
\text { Average }\end{array}$ & $\mathrm{R}$ & 0.01 & -0.05 & 0.03 & 0.09 \\
\cline { 2 - 6 } & $\mathrm{P}$ & 0.94 & 0.60 & 0.75 & 0.29 \\
\hline
\end{tabular}

It was found that participants' academic success level had no statistically significant relationship with 'Concrete Experience', 'Reflective Observation', 'Abstract Conceptualization' and 'Active Experimentation' learning levels of participants ( $>0.05)($ Table 3$)$.

Table 4:Breakdown of means of scores obtained by nursing students from Problem-Solving Inventory

\begin{tabular}{|l|l|l|l|}
\hline ScaleSub-Dimensions & $\begin{array}{l}\text { Scorerange } \\
{[\text { Min-Max] }}\end{array}$ & $\mathbf{X}$ & S.s. \\
\hline OverallScore & $32-192$ & 82,09 & 23,60 \\
\hline HastyApproach & $9-54$ & 17,60 & 5,75 \\
\hline AvoidingApproach & $4-24$ & 12,38 & 3,48 \\
\hline ThinkingApproach & $5-30$ & 11,40 & 4,23 \\
\hline EvaluativeApproach & $3-18$ & 11,62 & 3,12 \\
\hline Self-Confidence & $6-36$ & 17,65 & 4,61 \\
\hline PlannedApproach & $4-24$ & 12,73 & 3,86 \\
\hline
\end{tabular}

As per the table, means of scores obtained by nursing students from the overall Problem-Solving Inventory and its sub-scales demonstrate that nursing students had medium-level problem-solving skills (Table 4).

Table 5: Relationship between academic success levels and problem-solving skill levels

\begin{tabular}{|l|l|l|l|l|l|l|l|l|}
\hline \multicolumn{2}{|l|}{} & $\begin{array}{l}\text { HastyApp } \\
\text { roach }\end{array}$ & $\begin{array}{l}\text { ThinkingAp } \\
\text { proach }\end{array}$ & $\begin{array}{l}\text { AvoidingAp } \\
\text { proach }\end{array}$ & $\begin{array}{l}\text { EvaluativeAp } \\
\text { proach }\end{array}$ & $\begin{array}{l}\text { Self- } \\
\text { ConfidenceAp } \\
\text { proach }\end{array}$ & $\begin{array}{l}\text { PlannedAp } \\
\text { proach }\end{array}$ & $\begin{array}{l}\text { OverallS } \\
\text { core }\end{array}$ \\
\hline $\begin{array}{l}\text { Acade } \\
\text { mic } \\
\text { succes } \\
\text { s } \\
\text { levels }\end{array}$ & $\mathrm{r}$ & $0,21^{*}$ & $0,20^{*}$ & $0,29^{*}$ & $0,27^{*}$ & $0,26^{*}$ & $0,26^{*}$ & $0,29^{*}$ \\
\cline { 2 - 8 } & 0,01 & 0,01 & 0,01 & 0,01 & 0,01 & 0,01 & 0,01 \\
\hline
\end{tabular}

It was ascertained that participants' academic success levels had weak statistically significant positive relationship with hasty, thinking, avoidance, evaluating, self-confident, planned approaches and the overall problem-solving approach (Table 5).

Table 6: Relationship between sub-scales of Kolb Learning Style Inventory and the approaches of the Problem-Solving Inventory

\begin{tabular}{|l|l|l|l|l|l|}
\hline \multirow{7}{*}{} & Kolb sitili & $\mathrm{n}$ & $\mathrm{X}$ & s.s. & $\mathrm{p}$ \\
\hline \multirow{4}{*}{ HastyApproach } & & & & & \\
& Converging & 44 & 18,80 & 5,42 & \multirow{2}{*}{0,88} \\
\cline { 2 - 5 } & Diverging & 29 & 18,59 & 5,56 & \\
\cline { 2 - 5 } & Asimilating & 37 & 19,57 & 5,12 & \\
\cline { 2 - 5 } & Accomodating & 20 & 19,30 & 6,16 & \\
\cline { 1 - 5 } ThinkingApproach & Converging & 44 & 11,02 & 3,84 & \multirow{2}{*}{$0,02^{*}$} \\
\cline { 2 - 5 } & Diverging & 29 & 10,38 & 3,26 & \\
\hline
\end{tabular}




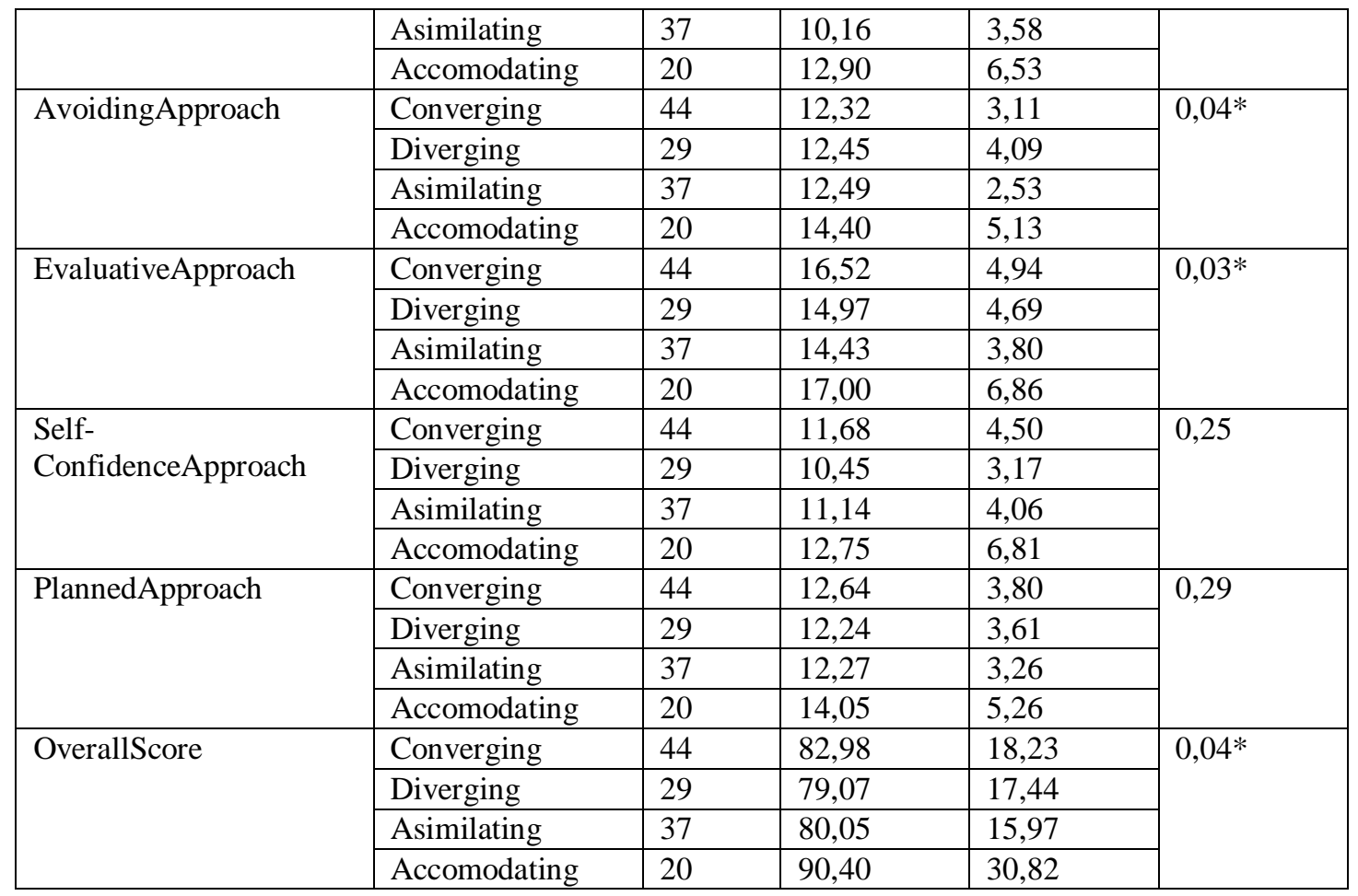

It was observed that participants' overall problem-solving approach levels had a statistically significant association with sub-scales of Kolb Learning Style Inventory ( $\mathrm{p}=0.04)$ (Table 6).

\section{Conclusion}

It is indispensable for nurses to have problem-solving skills so as toprovide good quality patient care and to assure the safety of patients. The learning style is a crucial factor for the development of students' problem-solving skills. In the relevant literature, there are several studies suggesting that students have different learning styles [36-38].Learning styles are directly associated with learning and the learning process. We believe that students' problem-solving skills will be promotedand their success levels will be significantly raised through education to be presented on students' learning styles.

\section{Recommendations}

We recommend that instructors should identify individuals' learning styles and should, on the basis of these identifications, design the instruction method, materials, elements reinforcing learning and content plans. In the relevant literature, the number of studies on this topic is not at the sufficient level. We suppose that this study will set an example for subsequent studies to be performed later on. Performing more studies on this topic will contribute to the nursing education.

\section{Ethical Consideration}

Before the start of the research, the ethics committee endorsement for the research was received from Cappadocia University. Students taking part in the research were asked to undersign the informed consent form and their agreement to join the research was obtained in written format.

\section{Reference}

1. Lau WW, Yuen AH. Promoting conceptual change of learning sorting algorithm through the diagnosis of mental models: The effects of gender and learning styles. Computers \& Education. 2010;54(1):275-88.

2. Arslan H, Uslu B. The relationship between preservice teachers' learning styles and leadership trends. Journal of Education and Science. 2014;39:173.

3. Arslan B, Babadoğan C. The relationship between the learning styles of primary school 7th and 8th grade students with academic achievement level, gender and age. Eurasian Journal of Educational Research. 2005;21:35-48.

4. An GJ, Yoo MS. Critical thinking and learning styles of nursing students at the baccalaureate 
nursing program in Korea. Contemporary Nurse. 2008;29(1):100-9.

5. Topuz FG, Karamustafaoğlu O. Analysıs Of Learnıng Styles In Terms Of Varıous Varıables: Science Teachers. Dicle University Journal of Ziya Gokalp Education Faculty. 2013;21.

6. Hasırcı ÖK. The Effect Of Teachıng Organızed According To Visual Learning Styles On Academic Success And Permanentity. Journal of Çukurova University Institute of Social Sciences.14(2):299-313.

7. Ertekin E. A study on learning and teaching styles: Selcuk University Institute of Science; 2005.

8. Şenyuva EA. Examining the learning styles of nursing students in terms of some variables. Journal of Education Management in Theory and Practice. 2009;15(2):247-71.

9. Atay S, İbiş T, Kartal F. Evaluation of Learning Styles of Çanakkale Onsekiz Mart University School of Health Students. Educational Research Congress. 2009:1-3.

10. Seven M, Bağcivan G, Kılıç S, Açıkel C. Determination of the learning styles of junior nursing students and investigation of the relationship between their learning styles and academic achivement. Gülhane Medical Journal. 2012;54(2):129-35.

11. Günüşen $N$, Üstün B. Hemşirelik öğrencilerinin problem çözme beceri düzeyleri ile kontrol odağ arasındaki ilişki. 2011.

12. Shahriar S. Nursing Students'preferred Learnıng Styles. 2007.

13. Öztürk Can H, Öner Ö, Çelebi E. Investigation of the effects of education on problem solving skills of university students. Firat Health Services Magazine. 2009;4(10):35-58.

14. Ültanir E, Gürcan Ültanır Y, Temel GÖ. The Examination of University Students' Learning Styles by Means of Felder-Silverman Index. Education \& Science/Egitim Ve Bilim. 2012;37:163.

15. Coffield F, Moseley D, Hall E, Ecclestone K. Should we be using learning styles? What research has to say to practice. 2004.

16. Karadağ M, Alparslan Ö, İşeri ÖP. Critical thinking disposition and learning styles of midwifery and nursing students. Cukurova Medical Journal. 2018;43(1):13-21.

17. Özen Y. Learning styles of social studies education students and their relationship with various variables [Example of Erzincan
University]. Journal of Academic View 2011;24(2):1-20.

18. Dikmen Y. Examining the learning styles of nursing students according to Kolb's learning styles model. Journal of Human Rhythm. 2015;1(3):100-6.

19. Shirazi F, Heidari S. The relationship between critical thinking skills and learning styles and academic achievement of nursing students. The Journal of Nursing Research. 2019;27(4):e38.

20. Erdoğan Ş. Comparison of learning and thinking styles of successful and unsuccessful students in physics lessons: Selcuk University Institute of Science; 2008.

21. Phuong NTA, Thuy THT, Mai BH, Minh DTN, Viet HHT, Van Anh BH, et al. Exploring Learning Styles in Students Attended ProblemBased Learning Package at Hue University of Medicine and Pharmacy. Journal of ProblemBased Learning. 2018;5(2):37-42.

22. Elkin N, Karadağlı F. Evaluation of problem solving skills of university students. 2015.

23. Koç Z, Koyuncu S, Sağlam Z. Problem solving skill levels of nursing and midwifery students and the affecting factors. Koç University Nursing Education and Research Journal 2015;12(1):4150.

24. Kantek F, Öztürk N, Gezer N, editors. Investigation of students' critical thinking and problem solving skills in a health college. International Conference on New Trends in Education and Their Implications; 2010.

25. Olgun N, Öntürk ZK, Karabacak Ü, Aslan Eti F, Serbest Ş. Problem solving skills of nursing students: one year follow-up results. 2010.

26. Seobuk-gu C-S. The relationship between problem solving ability, professional self concept, and critical thinking disposition of nursing students. International journal of BioScience and bio-technology. 2014;6(5):131-42.

27. Kanbay Y, Aslan Ö, Işık E, Kılıç N. Problem Solving and Critical Thinking Skills of Nursing Undergraduate Students. Journal of Higher Education \& Science. 2013;(3):1.

28. Yüksel A. Nursing students' problem solving self-evaluation results and affecting factors research. 2015.

29. Yoo M-S, Park J-H. Effect of case-based learning on the development of graduate nurses' problem-solving ability. Nurse Education Today. 2014;34(1):47-51.

30. Özyazıcıŏlu N, Aydınoğlu N, Aytekin G. Investigation Of Empatic And Problem Solving 
Sk1lls Of Health School Students. Anadolu Nursing and Health Sciences Journal. 2009;12(3):46-53.

31. Sardoğan ME, Karahan TF, Kaygusuz C. Analysis of the indecision strategies used by university students by problem solving skills, gender, grade level and faculty type. Mersin University Faculty of Education Journal. 2006;2(1):78-97.

32. Kolb DA. Experiential learning: Experience as the source of learning and development: FT press; 2014.

33. Kolb DA. The Kolb learning style inventory: Hay Resources Direct Boston, MA; 2007.

34. Kilic E. The effects of dominant learning style on academic achievement and preferred learning activities. Educational Sciences and Practice. 2002;1(1):1-15.
35. Dilci T. Evaluating the situation of postgraduate education in educational sciences from the perspective of students and academicians. 2009.

36. Cuthbert PF. The student learning process: Learning styles or learning approaches? Teaching in higher education. 2005;10(2):23549.

37. Yalız D, Erişti B. Learning styles of Anadolu University physical education and sports teacher education students. Journal of Physical Education and Sports Sciences. 2009 ;4(4):15663.

38. Tüysüz C, Tatar E. Effect of the Pre-Service Teachers' Learning Styles on Chemistry Achievement and Attitudes. Mustafa Kemal University Journal of Social Sciences Institute. 2008;5(9):97-107.

\section{Source of Support: Nil}

Conflict of Interest: Nil 